\title{
Mortality Pattern in White Giant and Soviet Chinchilla Rabbit Kits
}

\author{
N.K. Thakkar ${ }^{1}$, A.K. Srivastava ${ }^{1}$, A.P. Chaudhary ${ }^{3}$, H.D. Chauhan ${ }^{1}$, \\ K.J. Ankuya ${ }^{1}$, V.K. Patel $^{4}$, J.P. Gupta ${ }^{7}$ and J.V. Patel ${ }^{1}$
}

${ }^{1}$ Department of Livestock Production and Management, ${ }^{2}$ Department of Animal Genetics and Breeding, College of Veterinary Science and Animal Husbandry, ${ }^{3}$ C.P. College of Agriculture, SDAU, Sardarkrushinagar - 385 506, Gujarat, India

${ }^{4}$ Krishi Vigyan Kendra, Tharad, SDAU, Sardarkrushinagar, Gujarat, India

*Corresponding author

\section{A B S T R A C T}

\section{Keywords}

White Giant, Soviet Chinchilla, Rabbit, year, Season, Broiler, Kit and Mortality

Article Info

Accepted: 15 February 2019 Available Online: 10 March 2019
The data on mortality of White Giant and Soviet Chinchilla rabbit kits spread over four years (2014 to 2017) maintained at organized farm, was analyzed. All kits were reared in the cages under standard management practices and weaned at the age of 28 days. The overall annual mortality rate was observed $29.85 \%$ for kits up to six months of age during the study period, while highest mortality was recorded during the year $2014(52.87 \%)$. The results revealed that period has significant $(\mathrm{P}<0.01)$ effect on the mortality rate among kits. Mortality rate was higher in the Soviet Chinchilla $(38.39 \%)$ breed as compared to White Giant $(19.10 \%)$ breed, but difference was non-significant. The age wise mortality was observed higher in pre-weaning $(28.35 \%$ during $0-28$ days) than post weaning $(2.08 \%$ during 29-180 days) group. The mortality rate was higher in summer $(48.38 \% ; n=30)$ than monsoon $(22.82 \% ; n=21)$ and winter $(19.14 \% ; n=9)$, but analysis of variance revealed that effect of season on kits mortality was non-significant.

\section{Introduction}

The introduction of rabbit farming in India is becoming familiar day by day not only as an enterprise, but as human hobby, which may prove a source of livelihoods under disadvantage regions of the country. It has immense potential for sustainable food production to meet the requirement of growing population in the country, as this micro livestock species contributes meat, wool, fur, pelt and manure for cultivation of crops.
Rabbit rearing has great potential in the economy of high hilly areas (Tripathi and Pandey, 1986). The population of rabbit has increased from 0.424 million in 2007 to 0.592 million in 2012 with an increase of $39.55 \%$ (BAHS, 2012).

The rabbit (Oryctolagus cuniculus) known as "micro-livestock" species could be a good source of food production (Assan, 2014). There is great opportunity of rabbit farming (also known as "Cumiculture") and 
commercial production which can be a great source of income and employment, because rabbits required less space and food for survival. These animals can be raised successfully under backyard rearing system for meat for the family or for commercial enterprise (Gulyani and Karim, 2008), while its farming is encouraged for meat production under developing countries as these microenterprises are economical because of their early maturity, prolificacy and short gestation period (32 days). One female rabbit can give 6-7 liters in a year with 6 to 8 kits per kindling. It has biological productivity of 1025 times of its body weights in offspring's as compared to cow with 0.6 times and ewe 0.8 times as body weight during one year period (Srivastava et al., 2018). The meat obtained from rabbit is low in fat and cholesterol. It can minimize the protein gap in the dietary requirement and raise the income of rural and sub urban people. It can convert $20 \%$ of the protein they eat into edible meat, which is higher than beef (8-12\%; Basavaraj et al., 2011). The various environmental factors like year and season influence the mortality in rabbit kits, while mortality rate among rabbits is about $5-8 \%$. The present study was undertaken to investigate the effect of breed, age, season and period on the mortality of kits up to 6 months of age.

\section{Materials and Methods}

The data on mortality of White Giant and Soviet Chinchilla rabbit kits spread over four years (2014 to 2017) and maintained at Rabbit Unit, ILFC, Department of Livestock Production and Management, SDAU, Sardarkrushinagar, was collected and analyzed. The institute is located in north Gujarat at an altitude of 136 meters above the mean sea level. It lies at latitude of $24.35^{\circ}$ North and longitude of $72.59^{\circ}$ East and climate of the farm is semi-arid in nature. Environmental temperature varied from $16^{\circ}$ to $25^{\circ} \mathrm{C}$ in winter and $34^{\circ}$ to $45^{\circ} \mathrm{C}$ in summer with annual rainfall $600 \mathrm{~mm}$ (Gujarat-weather, 2017). Generally, winter (November to February) remains fairly cold and dry, summer (March to June) is moderately hot and humid, while monsoon (July to October) is hot and extremely humid.

All age groups of the rabbits were reared under similar management and climatic conditions, while pregnant does were kept in separate cage $(3 \times 2 \times 2 \mathrm{ft})$ post-mating after being tested positive for pregnancy by weight gain method as well as abdominal palpation. All kits were weaned at the age of 28 days and reared in the cages under standard management practices. After weaning (>29 days) the kits were kept in the separate cages in groups $(4 \times 2 \times 2 \mathrm{ft})$ under standard management practices. The incidence of mortality was studied as proportion of rabbit died due to different factors. The incidence of mortality was divided into two periods i.e. pre-weaning and post-weaning mortality, whereas, year was divided in to three seasons viz. winter (November to February), summer (March to June) and monsoon (July to October). The percentage of mortality was calculated on the basis of total kits born during the period of study. Data was tabulated and analyzed using Chi-square to draw meaningful inferences as per Snedecor and Cochran (1994).

\section{Results and Discussion}

The mortality pattern in Soviet Chinchilla and White Giant rabbits from birth to 180 days of age during various seasons is presented in the Table 1. All the 201 kits born during the period of investigation belongs to two genetic groups and overall annual mortality rate was observed as $29.85 \%$ for kits up to six months of age. The highest mortality was recorded during the year $2014(52.87 \%)$ followed by 2016 (14.28\%), $2015(13.88 \%)$ and 2017 
$(8.57 \%)$. These observations revealed that period have significant $(\mathrm{P}<0.01)$ effect on the mortality of kits. However, some of these values were lower than earlier reports; where it was $36.89 \%$ in hot and humid conditions of Orissa (Das and Nayak, 1991) and $37.81 \%$ in Sikkim (Chandra et al., 2013), while lower mortality rate $(25.77 \%)$ was reported by Ghosh (2009); and among New Zealand White kits mortality was vary from $2.34 \%$ to $15.23 \%$ with a mean value of 8.47 (Pasupathi et al., 2014). The differences between the present and earlier reports might be due to variation in genetic groups, environmental conditions and management practices followed for rearing of the animals. The mortality rate of Soviet Chinchilla and White Giant rabbits were recorded as $38.39 \%$ and $19.10 \%$ respectively. The lower percentage of mortality in White Giant might be due to better adaptability and disease resistant ability of the breed in the prevailing environment. However, statistically mortality was not significantly affected by difference of breed. These findings are in close agreement with the observations of Das and Nayak (1991). Bhasin and Singh (1995) and Ghosh (2009), where they also reported non-significant but higher mortality in Soviet Chinchilla.

Table.1 Age-wise mortality (\%) pattern in broiler rabbit (Soviet Chinchilla and White Giant)

\begin{tabular}{|c|c|c|c|c|}
\hline \multicolumn{2}{|c|}{ Factors } & \multicolumn{3}{|c|}{ Age wise mortality rate } \\
\hline & & & & Overall \\
\hline \multirow{6}{*}{ Year } & Overall mean & $28.35(57 / 201)$ & $2.08(3 / 144)$ & $29.85(60 / 201)$ \\
\hline & 2014 & $51.72(45 / 87)$ & $2.38(1 / 42)$ & $52.87(46 / 87)$ \\
\hline & 2015 & $12.5(9 / 72)$ & $1.58(1 / 63)$ & $13.88(10 / 72)$ \\
\hline & 2016 & $0.00(0 / 7)$ & $14.28(1 / 7)$ & $14.28(1 / 7)$ \\
\hline & 2017 & $8.57(3 / 35)$ & $0.00(0 / 32)$ & $8.57(3 / 35)$ \\
\hline & \multicolumn{4}{|c|}{ Chi square value $=20.46^{* *}$, Significant $(\mathrm{P}<0.01)$} \\
\hline \multirow{5}{*}{ Season } & Overall mean & $28.35(57 / 201)$ & $2.08(3 / 144)$ & $29.85(60 / 201)$ \\
\hline & Winter & $19.14(9 / 47)$ & $0.00(0 / 38)$ & $19.14(9 / 47)$ \\
\hline & Summer & $43.54(27 / 62)$ & $8.57(3 / 35)$ & $48.38(30 / 62)$ \\
\hline & Monsoon & $22.82(21 / 92)$ & $0.00(0 / 71)$ & $22.82(21 / 92)$ \\
\hline & \multicolumn{4}{|c|}{ Chi square value $=3.16$, Non significant } \\
\hline \multirow{5}{*}{ Breed } & Overall mean & $28.35(57 / 201)$ & $2.08(3 / 144)$ & $29.85(60 / 201)$ \\
\hline & White Giant & $16.85(15 / 89)$ & $2.70(2 / 74)$ & $19.10(17 / 89)$ \\
\hline & Soviet & $37.5(42 / 112)$ & $1.42(1 / 70)$ & $38.39(43 / 112)$ \\
\hline & Chinchilla & & & \\
\hline & \multicolumn{4}{|c|}{ Chi square value $=0.73$, Non significant } \\
\hline
\end{tabular}

Note : Figures in the parenthesis indicate number of died/ number of kits available at the beginning of the respective age

The highest rate of mortality has been recorded in the summer season $(48.38 \%$; $\mathrm{n}=30)$ followed by monsoon season $(22.82 \%$; $\mathrm{n}=21)$ and winter season $(19.14 \%$; $\mathrm{n}=9)$. Preweaning mortality was the highest in summer season $(43.54 \%$; $\mathrm{n}=27)$ followed by monsoon season $(22.82 \% ; \mathrm{n}=21)$ and winter season $(19.14 \% ; \mathrm{n}=9)$. However, statistical analysis revealed that effects of season on mortality rate in rabbit kits were non-significant. The higher mortality in the summer season may be attributed to the high temperature than 
optimum and fluctuation in the environmental temperature. As the climate of the region is semi-arid in nature where, temperature varied between $34-45^{\circ} \mathrm{C}$ and even sometimes goes beyond $45^{\circ} \mathrm{C}$. Environmental variation induces stress in animals thereby precipitating various infections might be leads to mortality. The results did not differ appreciably from the finding of Ghosh (2009) and Das (2012). Chandra et al., (2013) reported that the highest mortality was observed in rainy season in Angora rabbits in Sikkim.

Further, it is evident from the Table 1 that pre-weaning mortality rate $(28.35 \%$ during 0 28 days of age) was higher than the post weaning (2.08\% during 29-180 days of age) stages of life. It is also noted that during the perinatal period (0-7 days) mortality was recorded as high as $25.87 \%$, which accounts more than $86 \%$ of total kits mortality up to 6 months of age. Higher mortality in earlier age of life was also reported by Ghosh (2009). Most of the perinatal deaths were attributable to sudden changes in temperature, heat stress, excessive humidity and low thermoregulation capacity among kits. Hence, it may be inferred that the effect of season on mortality rate of meat type rabbit is non-significant; however, the period of life had significant effect on mortality pattern. It may be concluded that there is no significant effect of environmental factors on survivability pattern of White Giant and Soviet Chinchilla under semi arid region of North Gujarat in India.

In conclusion, the higher mortality in the summer season may be attributed to the sudden changes in temperature and environmental variation induces physiological stress in animals thereby precipitating various infections might be leads to mortality. Thereby, season seems to be very critical and kits should be given extra care to reduce the heat stress, which will help to reduce the mortality. Further, breeding should be planned to avoid kindling during summer. Maximum mortality occurs during perinatal period hence, this period is very critical and kits should be given extra care for their survival.

\section{Acknowledgement}

The authors are thankful to the Dean and Principal, College of Veterinary Science and Animal Husbandry, S.D. Agricultural University, Sardarkrushinagar, Gujarat, India for providing necessary facility for the research work.

\section{References}

Assan, N., 2014. Micro-livestock farming and food security in sub Saharan Africa. Journal of Animal Production Advances. 4 (4): 374-387.

BAHS, 2012. $19^{\text {th }}$ Livestock Census-2012, Basic Animal Husbandry Statistics. Department of Animal Husbandry, Dairying and Fisheries, Ministry of Agriculture and Farmer's Welfare, GoI., New Delhi.

Basavaraj, M., Nagabhushana, V., Prakash, N., Appannavar, M. M., Wagmare, P. and Mallikarjunappa, S., 2011. Effect of dietary supplementation of curcuma longa on the biochemical profile and meat characteristics of broiler rabbits under summer stress. Veterinary world. 4(1): 15-18.

Bhasin, V. and Singh, D., 1995. Pre weaning mortality in rabbits. International Journal of Animal Sciences. 10, 77-79.

Chandra, R., Karmakar, H. D., De, D. and Rahman, H., 2013. Mortality pattern in German Angora rabbits in Sikkim. The Indian Journal of small Ruminants. 19(3): 118-120.

Das, R. K. and Nayak, J. B., 1991. Performance of broiler rabbits under hot and humid conditions. Indian journal 
Animal Production and Management. 7(4): 219-224.

Das, S. K., 2012. Study on the different factors affecting mortality pattern of rabbit in India. Indian Journal of Animal Research. 46(1): 89-91.

Ghosh, N., 2009. Mortality pattern in broiler rabbits (Oryctolagus cuniculus) under warm humid conditions of West Bengal. Indian Journal of Animal Research. 43(2): 127-29.

Gujarat-weather, 2017. District-wise Rainfall figures over whole Gujarat, India Meteorological Department. Available at

http://www.gujaratweather.com/wordpr ess $/$ pageid $=15265$ accessed on $7^{\text {th }}$ November, 2018.

Gulyani, R. and Karim, S. A., 2008. Scope of broiler rabbit rearing for meat and fur in India. National symposium on safe meat for good health and environment, Veterinary College, Bangalore.

Pasupathi, K., Mathusamy, P., Gopi, H., Balasubramanyam, D. and Babu, M.,
2014. Survivability in New Zealand White breed of rabbits under farming condition in Tamilnadu. International Journal of Science Environment. 3(5): 1772-1777.

Snedecor, G. W. and Cochran, W. G., 1994. Statistical method. $8^{\text {th }}$ edition. Oxford and IBH Publishing Corporation, New Delhi.

Srivastava, A. K., Chaudhary, A. P., Chauhan, H. D. and Joshi, D. V., 2018. Rabbit farming for employment and nutritional security for disadvantages regions of India. In: Smallholders Livestock Producers in India- Compendium, ISAPM- Conference-2018 held at SDAU, Sardarkrushinagar. PP: 254260.

Tripathi, R. S. and Pandey, V. K., 1986. Perspective of agriculture development in Tehri district. Research report, G.B. Pant University of Agriculture and Technology, Ranichauri, Tehri Garhwal, pp: 3-5.

\section{How to cite this article:}

Thakkar, N.K., A.K. Srivastava, A.P. Chaudhary, H.D. Chauhan, K.J. Ankuya, V.K. Patel, J.P. Gupta and Patel, J.V. 2019. Mortality Pattern in White Giant and Soviet Chinchilla Rabbit Kits. Int.J.Curr.Microbiol.App.Sci. 8(03): 2075-2079. doi: https://doi.org/10.20546/ijcmas.2019.803.247 